Note

\title{
POTENTIAL OF ELEVEN EUCALYPTUS SPECIES FOR THE PRODUCTION OF ESSENTIAL OILS
}

\author{
Paulo Henrique Müller da Silva ${ }^{1}$; José Otávio Brito ${ }^{1 *}$; Francides Gomes da Silva Junior ${ }^{1}$ \\ ${ }^{I}$ USP/ESALQ - Departamento de Ciências Florestais, C.P. 09 - 13418-900 - Piracicaba, SP - Brasil. \\ *Corresponding author <jotbrito@esalq.usp.br>
}

\begin{abstract}
Most Eucalyptus plantations in Brazil aim the production of paper and charcoal, but the use of the species for lumbering, construction and extraction of essential oil has increased. Eleven species of Eucalyptus were assessed in regard to their essential oil production potential, nine never used before for commercial, essential oil extraction. Assessements were compared with Eucalyptus citriodora and Eucalyptus globulus, already explored in oil production for perfume and medical purposes, aiming to increase the availability of commercial species and the relationship between oil production and climatic conditions. Eucalyptus leaves were seasonally sampled (three months interval) for distillation and determination of productivity and chemical composition of oil - contents of oils main components. Eucalyptus viminalis showed the highest potential for cineol, and standed out among the species not yet used commercially. Influenced by soil moisture contents and air temperature, the lowest and the highest oil production happened respectively in Spring and Summer. Water deficiency in Spring caused the lowest oil production. In the Summer, on the other hand, the highest oil production was observed when temperatures were higher and no water deficiency registered. There was no climatic influence on the main oil chemical component.
\end{abstract}

Key words: Eucalyptus spp., essential oil, yield, climatic influence

\section{POTENCIAL DE ONZE ESPÉCIES DE EUCALIPTO PARA A PRODUÇÃO DE ÓLEOS ESSENCIAIS}

\begin{abstract}
RESUMO: A maioria das plantações de Eucalyptus brasileiras tem como objetivo a produção de papel e carvão, mas o uso das espécies para madeira, construção e extração de óleo essencial tem aumentado. Neste trabalho foram estudadas onze espécies de eucalipto quanto ao potencial para a obtenção de óleo essencial. Entre as espécies estudadas, nove não têm sido utilizadas na obtenção comercial de óleo. Para efeito comparativo, avaliou-se também duas outras espécies, o Eucalyptus citriodora e o Eucalyptus globulus, as quais são amplamente utilizadas, respectivamente, para a obtenção de óleo aromatizante e óleo para fins medicinais. Os objetivos do estudo foram ampliar o leque de materiais disponibilizados para os produtores de óleo essencial e correlacionar o rendimento de óleo com as variações climáticas existentes ao longo do ano. Foram realizadas coletas sazonais (cada 3 meses) de folhas para a destilação e determinação do rendimento e avaliação da composição química do óleo. Dentre as espécies ainda não utilizadas comercialmente, considerando-se o rendimento do óleo e os teores dos componentes principais, o Eucalyptus viminalis revelou-se aqueal de maior potencial para a exploração de óleo essencial rico em cineol, para uso medicinal. O menor e o maior rendimento de óleo foram obtidos, respectivamente, na primavera e no verão. A disponibilidade de água no solo e a temperatura do ar influenciaram o rendimento de óleo. Sob condições de deficiência hídrica, observada na primavera, ocorreu o menor rendimento de óleo. No verão, quando a temperatura foi mais elevada e não ocorreu deficiência hídrica, registrou-se o maior rendimento de óleo. Não foi observada influência das condições climáticas sobre o teor do componente químico principal do óleo, que se manteve constante nas quatro estações.

Palavras chave: Eucalyptus spp., rendimento, óleo essencial, influência climática
\end{abstract}

\section{INTRODUCTION}

Because of its silvicultural characteristics Eucalyptus is widely used for reforestation in Brazil; plantations fo from the Southern most Rio Grande do Sul to the Amazon Region, without any limitations for cultivation (Soares et al., 1983). Most plantations target the production of pulp/paper and charcoal to supply steel plants, but use for the lumbering, construction and essential oil extraction has increased. Essential oils 
extracted from Eucalyptus are used in cleaning products, food, perfume, medicine, etc (Penfold \& Willis 1961).

Essential oils are volatile, aromatic products that can be carried by steam, containing variable amounts of different classes of organic compounds (Boland et al., 1991; Vitti, 1999). According to Brilho (1967), the presence of these components in a product - in higher or lower quantities - directly affects its quality. Moreover, Penfold \& Willis (1961) report that the oil is found in many parts of the plants, but concentrate in the leaves, flowers, glandular hair, and secretion glands. This may introduce sources of variation in the products' final quality.

Brazil holds a large share in the international market, being one of the main producers of Eucalyptus essential oil (Vitti \& Brito 1999). However, little research is still available regarding the yield and quality improvement of such products (Xavier et al., 1996), most of references related to Eucayptus citriodora. However, because of Brazilian forestry development, several other Eucalyptus species were introduced, and many show potential for the essential oil extraction (Silva et al., 2002). This study evaluates the potential of Eucalyptus species for the production of essential oil and assess the correlation between oil production and the climate conditions.

\section{MATERIAL AND METHODS}

Leaves samples were obtained at Itatinga, SP,

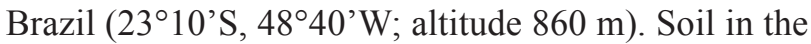
area varies from Oxisol Ultisol; climate is Cwa (Koeppe), annual average temperature $20.0^{\circ} \mathrm{C}$, and average annual rainfall $1,500 \mathrm{~mm}$. The temperature in the coldest month is around $4.0^{\circ} \mathrm{C}$ and the average tem- perature of the warmest month is circa $35.0^{\circ} \mathrm{C}$. The sdudied forest stand was planted in January, 1997, spaced $3.0 \mathrm{~m} \times 1.8 \mathrm{~m}$, a total of 450 plants per species. The crop received furrow fertilization, with a 10-2010 formulae at $150 \mathrm{~kg} \mathrm{ha}^{-1}$ (Table 1).

\section{Leaves sampling}

Trees that showed the best silviculture characteristics (diameter, height, trunk shape, visual crown appearance, etc) were selected, and the 10 best ones were chosen. Leaves were sampled from those trees in April (Fall), July (Winter), October (Spring), and January (Summer). Approximately $1.0 \mathrm{~kg}$ of green material from the crown of each tree, per each species, including leaves and branches was randomly collected, mixed, and a 500-g leaves composite sample was drawn, and taken to distilation.

\section{Leaves distillation}

Repetitive distillations were carried out using a Clevenger MA553 distillator, nominal volume 2.0 L. Leaves were distilled by immersion for one hour in a volume of $1.4 \mathrm{~L}$. The procedure was repeated 3 times per species. After distillation, the oil was collected and a small fraction of anhydrous sodium sulphate was added to eliminate aqueous residue, and the oil mass yield was determined.

\section{Gas chromatography}

A HP 5890 series II gas chromatographer, equiped with HP 20M (carbowax 20M) cappillary column, was used to determine the main components of the oil.

\section{Climatic comparisons}

The relationship between oil production and water balance data in the forest stand was assessed. Water balance data were collected from January $1^{\text {st }}$,

Table 1- Selected Eucalyptus species used in the study.

\begin{tabular}{ll}
\hline Eucalyptus Species & \multicolumn{1}{c}{ Origin } \\
\hline Eucalyptus benthami & Correia Pinto-SC $\left(27^{\circ} 35^{\prime} \mathrm{S}, 50^{\circ} 21^{\prime} \mathrm{W}\right)$ \\
$\begin{array}{l}\text { Eucalyptus camaldulensis } \\
\text { Eucayptus citriodora* }\end{array}$ & Anhembi-SP $\left(22^{\circ} 47^{\prime} \mathrm{S}, 48^{\circ} 07^{\prime} \mathrm{W}\right)$ \\
\hline Eucalyptus cloeziana & Anhembi-SP \\
Eucalyptus dunnii & Anhembi-SP \\
Eucayptus maculata & Anhembi-SP \\
Eucalyptus pellita & Anhembi-SP \\
Eucalyptus globulus $*$ & Anhembi-SP \\
Eucalyptus propinqua & Portugal $\left(38^{\circ} 42^{\prime} \mathrm{N}, 09^{\circ} 10^{\prime} \mathrm{W}\right)$ \\
Eucalyptus tereticornis & Anhembi-SP \\
Eucalyptus viminalis & Anhembi-SP \\
\hline
\end{tabular}

*Species traditionally used for essential oil production in Brazil. 
2003 to January $14^{\text {th }}, 2004$, to cover the whole sampling period.

\section{RESULTS AND DISCUSSION}

\section{Distillation}

Distillation results are presented in Table 2 and Figure 1. E. citriodora, E. viminalis and E. globulus had the highest yields along the year. Results confirm E. citriodora and E. globulus as the most important eucaplyptus oil source. That strengthens the existing references about the use and economic feasibility of such species (Maffeis et al., 2000). E. viminalis stood out among the other species assessed, showing high potential for oil production, far-followed by $E$. propinqua.

Nine out of the eleven species assessed presented reduction of oil yield during Spring, the exception being $E$. viminalis. The best production was registered for Summer, especially E. citriodora, E. maculata, and E. viminalis.

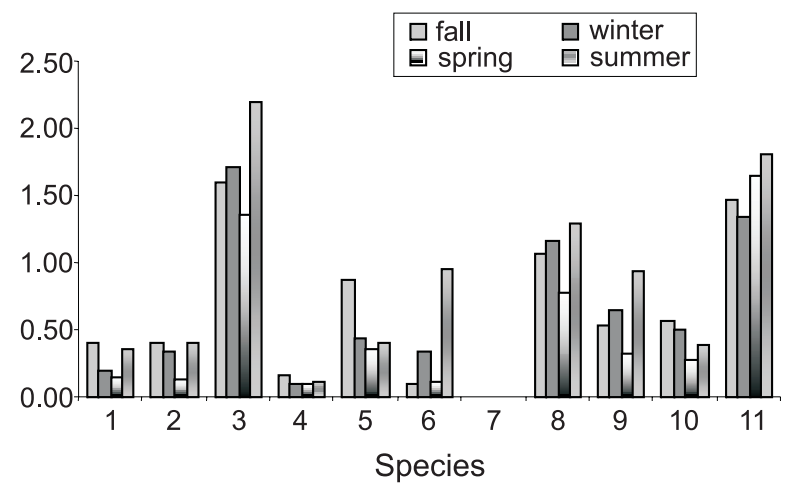

Figure 1 - Oil yield from destillation.

\section{Main oil chemical components}

Main chemical components of the essential oils and its contents (in comparison to compounds) are presented in Table 3 and Figure 2. Most species had cineol as the main component. Both E. benthami and $E$. cloeziana showed a-pynene as their main chemical component. As expected, E. citriodora showed citronellal as the main component.

\section{Climatic comparisons}

Table 4 shows the Water Balance of the forest stand; water deficiency is observed mainly in the Spring. The rain season started on October and sampling was carried out on the beginning of this month. Therefore, October sampling was carried at the peak of the dry season. Figure 3 depicts the climate influence on the production of oil. The period in which the lowest production from the distillation was obtained is related especially to the water deficiency (Spring sampling). That has happened to all the species, except $E$. viminalis. The best production of all the spe-

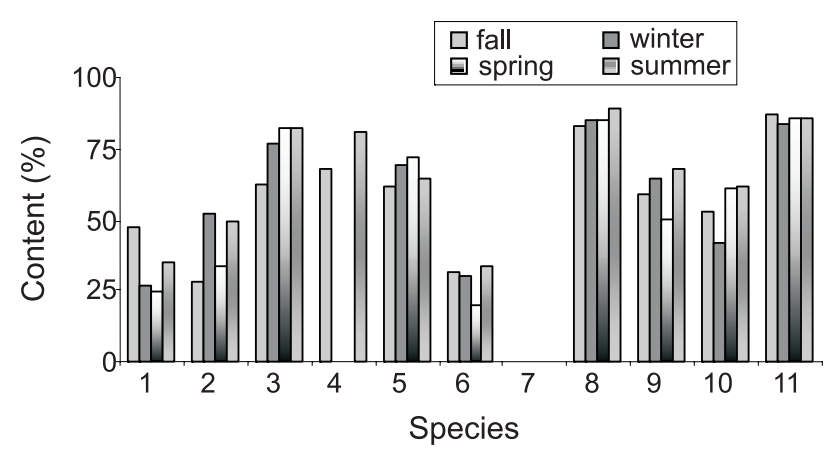

Figure 2 - Main oil chemical component contents.

Table 2 - Oil yield of selected Eucalyptus species.

\begin{tabular}{|c|c|c|c|c|c|}
\hline Species & Fall & Winter & Spring & Summer & Average \\
\hline \multicolumn{6}{|c|}{ - $\%$ } \\
\hline E. benthami & 0.40 & 0.20 & 0.15 & 0.35 & 0.27 \\
\hline E. camaldulensis & 0.40 & 0.33 & 0.13 & 0.41 & 0.32 \\
\hline E. citriodora & 1.59 & 1.70 & 1.35 & 2.15 & 1.70 \\
\hline E. cloeziana & 0.17 & 0.10 & 0.09 & 0.12 & 0.12 \\
\hline E. dunni & 0.86 & 0.43 & 0.35 & 0.41 & 0.51 \\
\hline E. maculata & 0.10 & 0.33 & 0.11 & 0.95 & 0.37 \\
\hline E. pelita & 0.00 & 0.00 & 0.00 & 0.00 & 0.00 \\
\hline E. globulus & 1.06 & 1.16 & 0.77 & 1.29 & 1.07 \\
\hline E. propinqua & 0.53 & 0.64 & 0.32 & 0.93 & 0.61 \\
\hline E. terenticornis & 0.57 & 0.50 & 0.27 & 0.38 & 0.43 \\
\hline E. viminalis & 1.46 & 1.33 & 1.64 & 1.80 & 1.56 \\
\hline
\end{tabular}


Table 3 - Main oil chemical component contents.

\begin{tabular}{lllllll}
\hline Species & Fall & Winter & Spring & Summer & Average & Main component \\
\hline E. benthami & 47.6 & 26.4 & 24.2 & 34.7 & 33.2 & $\alpha$-pynene \\
\hline E. camaldulensis & 28.0 & 52.1 & 33.2 & 50.0 & 40.8 & Cineol \\
E. citriodora & 62.8 & 77.0 & 82.0 & 82.4 & 76.1 & Citronellal \\
E. cloeziana & 67.8 & $\mathrm{ND}$ & $\mathrm{ND}$ & 81.9 & 74.9 & $\alpha-$ pynene \\
E. dunni & 61.8 & 69.4 & 72.0 & 64.7 & 67.0 & Cineol \\
E. maculata & 31.6 & 30.0 & 20.0 & 33.1 & 28.7 & Cineol \\
E. pelita & $\mathrm{ND}$ & $\mathrm{ND}$ & $\mathrm{ND}$ & $\mathrm{ND}$ & $\mathrm{ND}$ & ND \\
E. globulus & 83.0 & 85.0 & 84.8 & 89.0 & 85.5 & Cineol \\
E. propinqua & 59.5 & 64.4 & 50.1 & 68.1 & 60.5 & Cineol \\
E. terenticornis & 53.4 & 42.2 & 61.4 & 62.0 & 54.8 & Cineol \\
E. viminalis & 87.3 & 83.8 & 85.8 & 85.7 & 85.6 & Cineol \\
\hline
\end{tabular}

ND - not detectable.
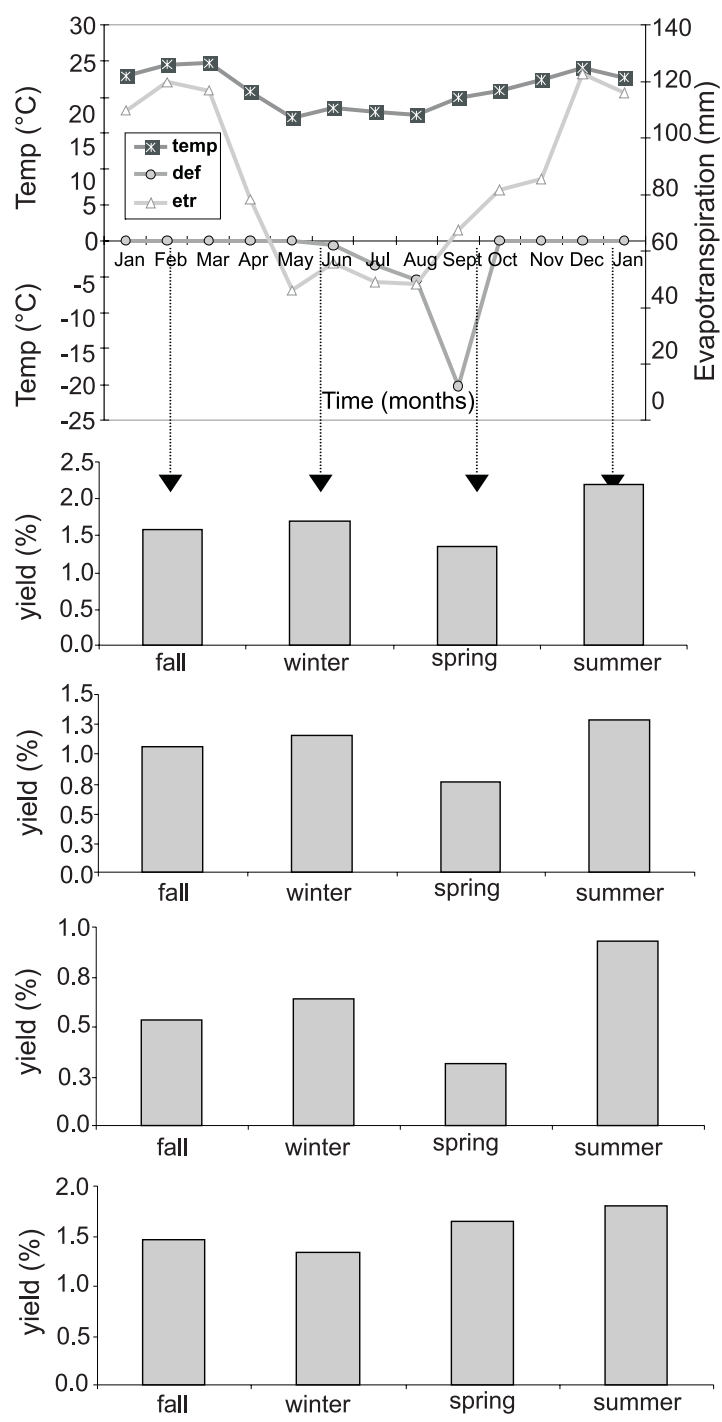

Legend:

temp - Average temperature

def - Water Deficiency

etr - Real Evapo-transpiration

Eucalyptus globulus

Eucalyptus propinqua

Eucalyptus viminalis

Figure 3 - Climate variation and oil production. 
Table 4 - Water balance in the forest stand.

\begin{tabular}{|c|c|c|c|c|c|c|c|c|c|c|c|c|c|c|}
\hline Months & Days & Temp & Precip. & Hours & I & $\mathrm{a}$ & $\begin{array}{c}\text { ETP } \\
\text { Thornthwaite } \\
1948\end{array}$ & P-ETP & NEG-AC & STOR & ALT & ETR & DEF & Surplus \\
\hline & & ${ }^{\circ} \mathrm{C}$ & $\mathrm{mm}$ & & & & & $\mathrm{mm}$ & & --.-- & 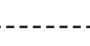 & mm -- &.--- & ----- \\
\hline Jan & 31 & 22.9 & 256.9 & 13.5 & 10.0 & 2.1 & 109.8 & 147.1 & 0.0 & 100.0 & 0.0 & 109.8 & 0.0 & 147.1 \\
\hline Feb & 28 & 24.5 & 166.1 & 13.1 & 11.1 & 2.1 & 120.0 & 46.1 & 0.0 & 100.0 & 0.0 & 120.0 & 0.0 & 46.1 \\
\hline Mar & 31 & 24.7 & 167.2 & 12.5 & 11.2 & 2.1 & 116.8 & 50.4 & 0.0 & 100.0 & 0.0 & 116.8 & 0.0 & 50.4 \\
\hline Apr & 30 & 20.8 & 110.8 & 11.8 & 8.6 & 2.1 & 78.5 & 32.3 & 0.0 & 100.0 & 0.0 & 78.6 & 0.0 & 32.3 \\
\hline May & 31 & 17.2 & 60.6 & 11.1 & 6.4 & 2.1 & 46.3 & 14.3 & 0.0 & 100.0 & 0.0 & 46.3 & 0.0 & 14.3 \\
\hline Jun & 30 & 18.5 & 44.7 & 10.6 & 7.2 & 2.1 & 55.8 & -11.1 & -11.1 & 89.5 & -10.4 & 55.2 & 0.6 & 00 \\
\hline July & 31 & 18.0 & 30.2 & 10.5 & 6.9 & 2.1 & 49.1 & -18.9 & -30.0 & 74.1 & -15.4 & 45.7 & 3.5 & 0.0 \\
\hline Aug & 31 & 17.5 & 30.8 & 10.9 & 6.6 & 2.1 & 48.0 & -17.2 & -47.2 & 62.4 & -11.6 & 42.6 & 5.5 & 0.0 \\
\hline Sept & 30 & 20.0 & 26.2 & 11.5 & 8.1 & 2.1 & 67.6 & -41.4 & -88.5 & 41.2 & -21.1 & 47.4 & 20.2 & 0.0 \\
\hline Oct & 31 & 20.9 & 101.2 & 12.2 & 8.7 & 2.1 & 81.5 & 20.4 & -68.2 & 50.5 & 9.3 & 81.6 & 0.0 & 0.0 \\
\hline Nov & 30 & 22.4 & 184.7 & 12.9 & 9.7 & 2.1 & 85.5 & 99.1 & 0.0 & 100.0 & 49.4 & 85.6 & 0.0 & 49.7 \\
\hline Dec & 31 & 24.1 & 139.2 & 13.4 & 10.8 & 2.1 & 122.6 & 16.6 & 0.0 & 100.0 & 0.0 & 122.6 & 0.0 & 16.6 \\
\hline Jan* & 30 & 22.7 & 135.0 & 13.5 & 9.8 & 2.1 & 110.0 & 25.0 & 0.0 & 100.0 & 0.0 & 110.0 & 0.0 & 25.0 \\
\hline total & & 274.6 & 1454.8 & 157.5 & 115.9 & 27.8 & 1092.0 & 362.8 & & 1117.8 & 0.0 & 1062.2 & 29.8 & 381.5 \\
\hline average & & 21.1 & 111.6 & 12.1 & 8.9 & 2.1 & 83.8 & 27.9 & & 85.9 & & 81.5 & 2.3 & 29.3 \\
\hline
\end{tabular}

*Data corresponding to the first 13 days of the month.

cies happened in the Summer, when climatic conditions showed the highest real evapotranspiration rate, with higher temperatures and no water deficiency. No correlation between chemical component and climatic variations was found.

\section{ACKNOWLEDGEMENTS}

Authors thank co-ordinators and employees of Estação Experimental de Ciências Florestais de Itatinga for their support. Thanks are also due to Fundação de Amparo à Pesquisa do Estado de São Paulo (FAPESP) for the scholarship granted to the first author.

\section{REFERENCES}

BOLAND, D.J.; BROPHY, J.J.; HOUSE, A.P.N. Eucalyptus leaf oils use, chemistry, distillation and marketing. Melbourne: INKATA; ACIAR; CSIRO, 1991.247p.

BRILHO R.C. A destilação de óleos essenciais. Campinas: CETREC, 1967. 20p.

MAFFEIS, A.R.; Silveira, R.L.V.A.; Brito, J.O. Reflexos das deficiências de macronutrientes e boro no crescimento de plantas, produção e qualidade de Óleo essencial em Eucalyptus citriodora. Scientia Forestalis, v.57, p.87-98, 2000 .
PENFOLD, A.R.; WILLIS, J.L. The eucalypts - botany, cultivation, chemistry and utilization. Lodon: Leonard Hill, 1961. 550p.

SILVA, P.H.M.; BRITO, J.O.; WAGEMAKER, T.A.L.; GABRIEL, M.V. Estudo preliminar de novas espécies de Eucalyptus para produção de óleo essencial no Brasil. In: SIMPÓSIO INTERNACIONAL DE INICIAÇÃO CIENTIFICA DA UNIVERSIDADE DE SÃO PAULO, 10., Piracicaba, 2002. Resumos. São Paulo: USP, 2002.

SOARES,V.P.; PAULA, F.; SCOLFORO, J.R.S. Analise da relação hipsometrica diametro-altura e das alturas médias, em povoamentos jovens de Eucalyptus grandis no município de Lassance - MG. Silvicultura, v.8, p.702-704, 1983.

VITTI, A.M.S. Avaliação do crescimento e do rendimento e qualidade do óleo essencial de procedência de Eucalyptus citriodora. Piracicaba: USP/ESALQ, 1999. 71p. (Dissertação-Mestrado).

VITTI, A.M.S.; BRITO, J.O. Avaliação do rendimento e do teor de citronelal do óleo essencial de procedências e raças locais de Eucalyptus citriodora. Scientia Forestalis, v.56, p.145-154, 1999.

XAVIER, A.; SILVEIRA, A.M.; BRITO, J.O. Melhoramento de Eucalyptus spp. na produção de óleo essencial. In: SIMPOSIO IPEF, 6., São Pedro, 1996. Anais. Piracicaba: IPEF, 1996. v.3, p.21-28.

Received August 02, 2004

Accepted November 24, 2005 